Annals of Plant Sciences

ISSN: 2287-688X

OPEN ACCESS

Research Article

www.annalsofplantsciences.com

\title{
Palyno-taxonomic study of some members of Malvaceae in Purba Medinipur, West Bengal, India.
}

Sandip Kumar Maity ${ }^{1}$, Arjun Patra ${ }^{2}$, Bikram Pal ${ }^{1}$ and Arati Malakar ${ }^{1^{*}}$

${ }^{1}$ Department of Botany, Tamralipta Mahavidyalaya, Tamluk- 721 636, West Bengal, India.

${ }^{2}$ Department of Botany, Prabhat Kumar College, Contai- 721 401, West Bengal, India.

Received: 1/16/2018; Accepted: 1/26/2018

\begin{abstract}
The Malvaceae is a large family of about 243 genera and 4225 species with medicinal and gardening importance. Palynological observations were carried out of 9 species collected from different localities of Purba Medinipur District during the period of February 2016 to December 2017. The present study reveals the pollen morphological characteristics, especially pollen shape classes like Oblate (1 species), Oblate-spheroidal (4 species), Subprolate (1 species) and Per-oblate (3 species) with diameter ranges between $35 \mu \mathrm{m}$ (Urena lobata L.) to $115 \mu \mathrm{m}$ (Malvaviscus arboreus Cav.). Pollen morphology is one of the most significant tool for the taxonomic study as well as systematics of plant taxa.
\end{abstract}

Keywords: Pollen Morphology, Malvaceae, Eurypalynous, Purba Medinipur

\section{Introduction}

Malvaceae, the mallow family (order Malvales) containing 243 genera and at least 4,225 species of herbs, shrubs, and trees. Representatives occur in all except the coldest parts of the world but are most numerous in the tropics (Hutchinson, 1967; Bates, 1968; Fryxell, 1975 and 1988; Krebs, 1994). Now a day's study of pollen is an important area of research. Various pollen morphological features such as symmetry, shape, apertural pattern and exine configuration are very conservative features for the taxonomic assessment of the plants (Perveen, 2006; Bera et al., 2007; Keshavarzi et al., 2012). The usefulness of pollen morphology as an interpretative key for a natural classification is now debated (Blackmore and Barnes, 1991; Nilsson \& Praglowsky, 1992).

Pollen grains are widely used tool for taxonomical analysis of angiosperic plants. Taxonomists and botanists have recognized the necessity of pollen morphology in clarifying the classification of angiospermic plant groups upto species level or even upto variety level. Mature angiospermic pollen grains are unusual vegetative cells that contain sperm cells and complete with cell walls and plasma membranes (Sarkar et al., 2017). This arrangement is accomplished soon after meiosis, when an asymmetric mitotic division produces a large cell that engulfs its diminutive sister, the generative cell (Yang and Sundaresan, 2000).

Morphological characteristics of pollen grains also can be useful characters in studies of plant taxonomy because many pollen traits are influenced by the strong selective forces involved in various

*Corresponding Author:

Dr. Arati Malakar,

Associate Professor and Head,

Department of Botany,

Tamralipta Mahavidyalaya, India.

E-mail: arbot003@rediffmail.com reproductive processes, including pollination, dispersal, and germination (Erdtman 1952; Moore et al. 1991; Nowicke and Skvarla 1979; Stuessy 1990). Various pollen morphological features such as symmetry, shape, apertural pattern and exine configuration are very conservative features for the taxonomic assessment of the plants (Perveen, 1993). Pollen morphological data have also used by Dahlgren and Clifford (1982) and Dahlgren et al. (1985) during comparative studies and toward a more natural, phylogenetic system of classification of the monocotyledons. Zavada (1983) summarized the apertures and wall structures of monocot pollen and discussed evolutionary trends for those characters. Since then there has been a gradual increase in the use of pollen morphological data in phylogenetic analyses (Siddiqui and Qaiser, 1988; Goldblatt et al., 1991; Chaturvedi et al., 1998; and Furness and Rudall, 2003).

The present study aimed to compare pollen morphology of different species with same family and to improve the general knowledge of palynology to contribute the preparation of regional pollen flora.

\section{Materials and Methods}

The study was carried out during the period of February 2016 to December 2017. The plant specimen are collected from the different localities of Purba Medinipur district, West Bengal. The specimens were identified by standard taxonomic tool. The collected taxa are Abutilon indicum, Hibiscus brackenridgei, Hibiscus diversifolius, Hibiscus rosa-sinensis, Hibiscus waimeae, Malvaviscus arboreus, Sida cordifolia, 
Sida humilis and Urena lobata. The mature flowers of the above plant taxa were collected from healthy plants and pollen morpho types studied by Acetolysis method according to Erdtman, 1960. Pollen morphological characters were studied under Light Microscope (Magnus MLX- Model No. 13A315).

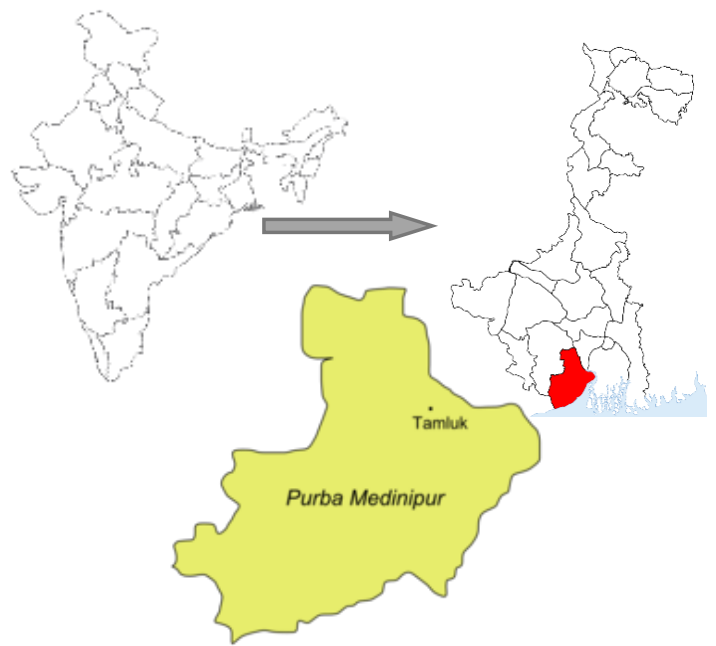

Fig. 1. Study area from which specimen are collected.
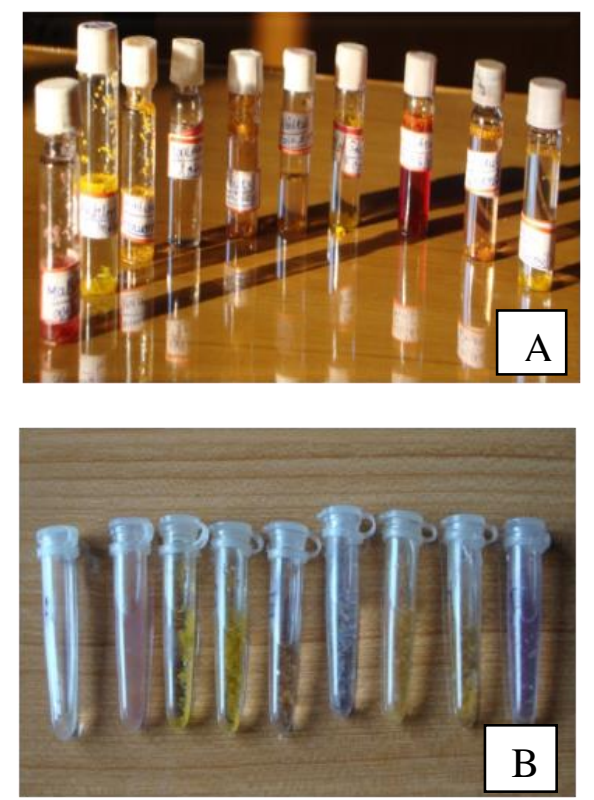

Figure 2. (A) Sample preservation before centrifuge, (B) Sample after centrifuge.

\section{Description of observed Pollen grains:}

During the present work pollen morphology of 09 species belong to Malvaceae family were studied and photographs are taken under Light Microscopy (LM). The flowering period of the studied taxa are was recorded in Table-1.

\section{Abutilon indicum (Link) Sweet}

Pollen $56 \mu \mathrm{m}$ in diameter, Oblate in shape, colporate or porate, spines short, pointed or tapering apices.

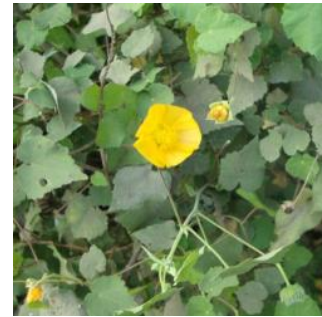

Fig. 3: Abutilon indicum

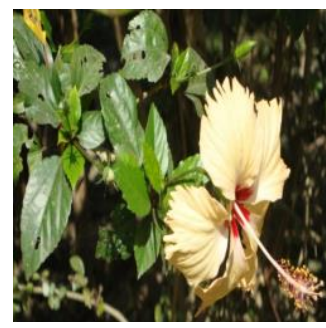

Fig.5: Hibiscus brackenridgei

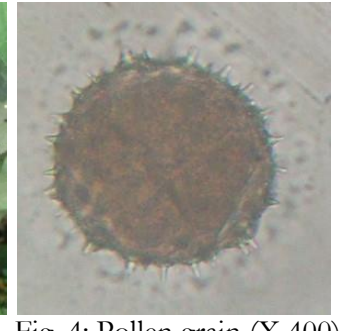

Fig. 4: Pollen grain (X 400)

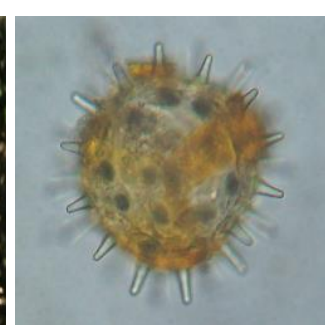

Fig. 6: Pollen grain (X 400)

\section{Hibiscus brackenridgei A. Gray}

Pollen are $95 \mu \mathrm{m}$ in diameter, apolar, Oblatespheroidal, polypantoporate, aperture in spiral pattern, spines long, straight, slender, blunt apices.

\section{Hibiscus diversifolius Jacq.}

Pollen are $92 \mu \mathrm{m}$ in diameter, apolar, Oblatespheroidal, polypantoporate, spine long, straight, slender, blunt apices.

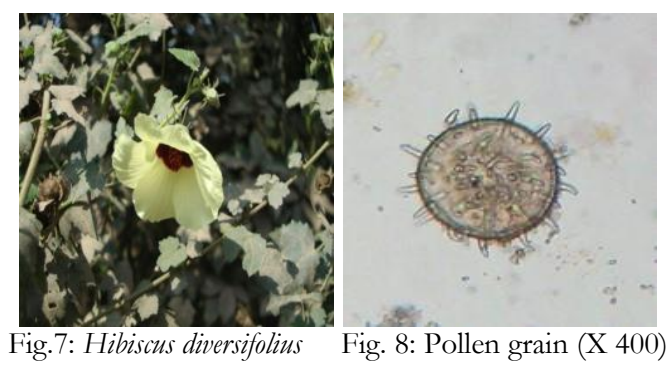

Hibiscus rosa-sinensis $\mathrm{L}$.

Pollen $96 \mu \mathrm{m}$ in diameter, apolar, Oblatespheroidal, colporate or porate, spine short, blunt apices.
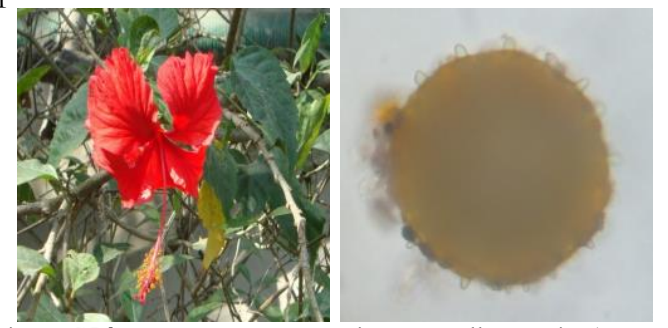

Fig. 9: Hibiscus rosa-sinensis

Fig. 10: Pollen grain (X 400)

\section{Hibiscus waimeae A. Heller}

Pollen 99 in diameter, oblate- spheroidal, apolar, polypantoporate, spine long, slender, straight, tapering apices. 


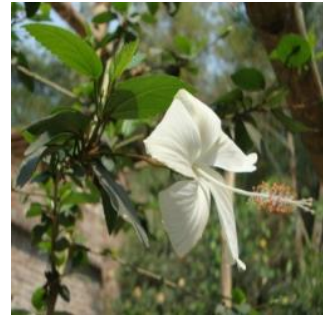

Fig. 11: Hibiscus waimeae

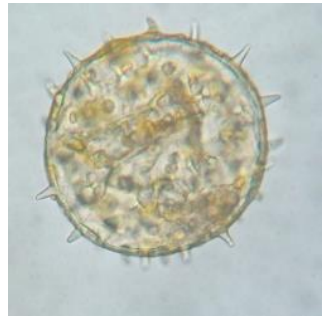

Fig. 12: Pollen grain (X 400)

Malvaviscus arboreus Cav.

Pollen $115 \mu \mathrm{m}$ in diameter, Sub-prolate, apolar, polypantoporate, pores numerous, spines long, straight, pointed apices.

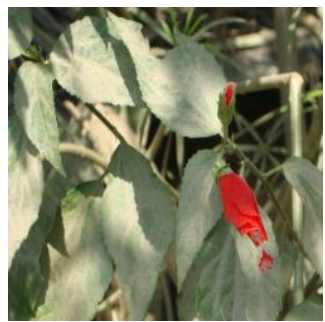

Fig.13. Malvaviscus arboreus

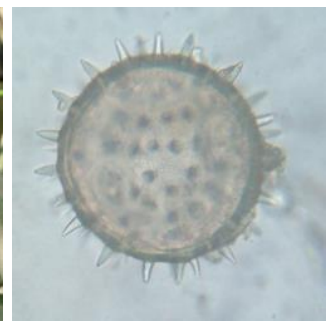

Fig. 14: Pollen grain (X 400)

Sida cordifolia L.

Pollen $45 \mu \mathrm{m}$ in diameter, Per-oblates, colporate or porate, spine short, rounded apices.

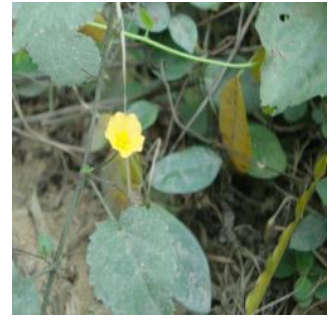

Fig.15. Sida cordifolia

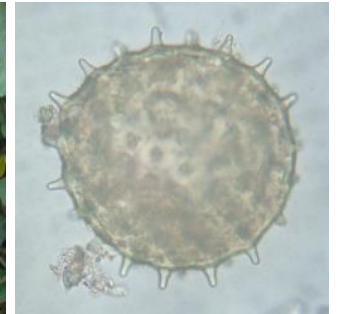

Fig. 16: Pollen grain (X 400)

\section{Sida humilis L.}

Pollen $47 \mu \mathrm{m}$ in diameter, Per-oblate, colporate or porate, spine short, pointed or tapering apices.

\section{Urena lobata L.}

Pollen $35 \mu \mathrm{m}$ in diameter, Per-oblate, polypantoporate, spine short, blunt apices.

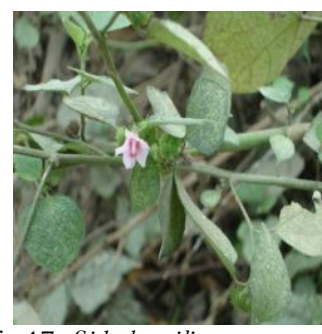

Fig.17: Sida bumilis

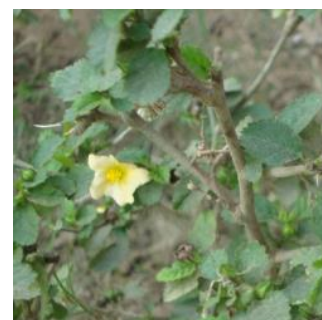

Fig.19: Urena lobata

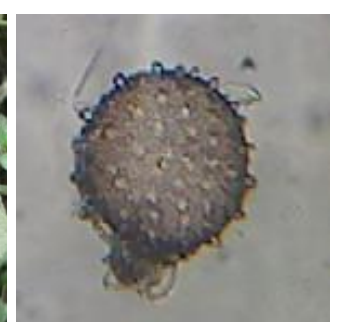

Fig. 18: Pollen grain (X 400)

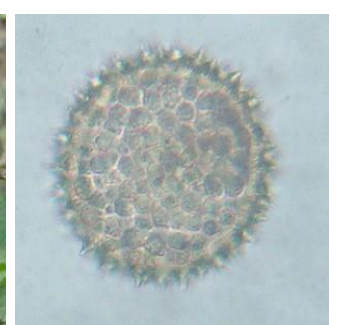

Fig. 20: Pollen grain (X 400)

Table 1. Comparative Assessment of pollen morphology among the plants belongs the family Malvaceae.

\begin{tabular}{|c|c|c|c|c|c|c|}
\hline Investigated plant & $\begin{array}{l}\text { Flowering } \\
\text { time }\end{array}$ & $\begin{array}{l}\text { Pollen grain } \\
\text { Diameter }(\mu \mathrm{m})\end{array}$ & Shape & $\begin{array}{c}\text { Aperture } \\
\text { arrangement }\end{array}$ & $\begin{array}{l}\text { Apertures } \\
\text { shape }\end{array}$ & Spine \\
\hline Abutilon indicum (L.) Sw. & $\begin{array}{l}\text { Throughout } \\
\text { the season }\end{array}$ & 56 & Oblate & Panto porate & $\begin{array}{l}\text { Colporate or } \\
\text { porate }\end{array}$ & Spines short, pointed or tapering apices. \\
\hline Hibiscus brackenridgei A. Gray & Feb - May & 95 & $\begin{array}{l}\text { Oblate- } \\
\text { spheroidal }\end{array}$ & Panto porate & Porate & $\begin{array}{c}\text { Spines long, straight, slender, blunt } \\
\text { apices. }\end{array}$ \\
\hline Hibiscus diversifolius Jacq. & Mar - June & 92 & $\begin{array}{l}\text { Oblate- } \\
\text { spheroidal }\end{array}$ & Panto porate & Porate & Spine long, straight, slender, blunt apices \\
\hline Hibiscus rosa-sinensis $\mathrm{L}$. & $\begin{array}{l}\text { Throughout } \\
\text { the season }\end{array}$ & 96 & $\begin{array}{l}\text { Oblate- } \\
\text { spheroidal }\end{array}$ & Panto porate & $\begin{array}{l}\text { Colporate or } \\
\text { porate }\end{array}$ & Spine short, blunt apices \\
\hline Hibiscus waimeae A. Heller & Feb - May & 99 & $\begin{array}{l}\text { Oblate- } \\
\text { spheroidal }\end{array}$ & Panto porate & Porate & $\begin{array}{c}\text { Spine long slender, straight, tapering } \\
\text { apices. }\end{array}$ \\
\hline Malvaviscus arboreus Cav. & May - Nov & 115 & Sub-prolate & Panto porate & porate & Spine long, straight, pointed apices. \\
\hline Sida cordifolia $\mathrm{L}$. & Oct - Dec & 45 & Per-oblate & Panto porate & $\begin{array}{l}\text { Colporate or } \\
\text { porate }\end{array}$ & Spine short, rounded apices \\
\hline Sida bumilis L. & Oct - Dec & 47 & Per-oblate & Panto porate & $\begin{array}{l}\text { Colporate or } \\
\text { porate }\end{array}$ & Spine short, pointed or tapering apices \\
\hline Urena lobata $\mathrm{L}$. & Apr - Nov & 35 & Per-oblate & Panto porate & Porate & Spine short, blunt apices \\
\hline
\end{tabular}

\section{Discussion}

Pollen morphology of Malvaceae is generally eurypalynous type. From the above study, the shape classes of pollen grains were observed as Oblate in Abutilon indicum, Oblate-spheroidal in Hibiscus brackenridgei, Hibiscus diversifolius, Hibiscus waimeae and Hibiscus rosa-sinensis, Sub-prolate in Malvaviscus arboreus and Per-oblate in Sida cordifolia, Sida bumilis and Urena lobata. The shape of the pollen grains were varied depending on the diameter $(\mu \mathrm{m})$ of pollen grain. Out of investigated taxa the smallest diameter pollen grain is Urena lobata $(35 \mu \mathrm{m})$ while the largest one is Malvaviscus arboreus $(115 \mu \mathrm{m})$. The 
spines are short, pointed or tapering apices; short, blunt or rounded apices; long, straight, slender, tapering or blunt apices.

The pollen morphology of Fabaceae, out of 16 plant species tri-colporate (3-colporate) type of pollen grains were observed in 13 species and The polyad types of pollen grains were found in Acacia auriculiformis, Acacia arabica and Albizzia lebbek (Bhattacharya et al., 2015). Pollen morphology of 22 species belonging 10 families were studied. Out of 22, Oblate-Spheroidal type is 5 species, Prolate type is 5 species, oblate type is 2 species, Triangular and Spheroidal type were also observed. Species belonging to same family also differ in pollen morphology (Sarkar et al., 2017).

\section{Conclusion}

The present comparative assessment was done considering the morphological variation of pollen grains of some plants belong to Malvaceae which are important for medicinal use as well as Gardening use. These pollen morphological characteristics can be correlate with other characteristics like leaf architecture, phytochemicals, cytology, anatomy and seed character may significant in the subject of practical based means applied prospect in the systematics of plants. This study will also helpful for the preparation of pollen calendar of an area with foraging habit of honey bee species.

\section{Acknowledgement}

Authors are thankful to Department of Botany of Tamralipta Mahavidyalaya for the kind cooperation during laboratory study.

\section{References}

1. Bates DM. "Generic relationships in the Malvaceae. tribe Malveae”. Gentes Herbarum 10 (1968): 117-135.

2. Bera SK, SK Basumatary, S Dixit. "Studies on pollen morphology and phenological characteristics of some economically important arborescent taxa of tropical forest, lower Brahmaputra valley, Assam, North East India". Journal of Palynology 43 (2007): 1-19.

3. Bhattacharya (Sasmal) P, S Biswas, JK Pal. " Palynotaxonomic study of some plant taxa of Fabaceae from Arambagh region of Hooghly district, West Bengal, eastern India”. Bioscience Discovery 6.1 (2015): 27-34.

4. Blackmore S, SH Barnes. "Palynological Diversity.- In: Pollen \& Spores". Clarendon Press, Oxford 44 (1991): 1-8.

5. Chaturvedi M, K Datta, PK Nair. "Pollen morphology of Oryza (Poaceae)". Grana 37(1998):79-86.
6. Dahlgren RM, HT Clifford. "The Monocotyledon, a Comparative Study”. Academic Press, New York 1982.

7. Dahlgren RM, HT Clifford, PF Yeo. "The Families of the Monocotyledons”. Berlin, Springer 1985.

8. Erdtman G. "The acetolysis method - A revised description”. Sven Botan Tidskr 54(1960): 561-4.

9. Fryxell P. “A. Generic relationships of Decaschistia (Malvaceae) and the description of a new tribe Decaschistieae". Amer Jour Bot 62(1975): 172-175.

10. Furness CA, PJ Rudall. "Aperture with lids: Distribution and signifcance of operculate pollen in monocotyledons". Int. J Plant Sci. 164(2003): 835-54.

11. Hutchinson J. "The genera of flowering plants (Angiospermae) Dicotyledones". Clarendon Press, London 2(1967): 659 .

12. Goldblatt P, JC Manning, A Bari. "Sulcus and operculum structure in the pollen grains of Iridaceae subfamily Ixioideae”. Ann Mo Bot Gard 78(1991): 950-61.

13. Krebs G. "Taxonomische Untersuchungen in der Subtribus Malvinae". Feddes Repert 105(1994): 7-18.

14. Keshavarzi M, S Abassian, M Sheidai. "Pollen morphology of the genus Clypeola (Brassicaceae) in Iran". Phytologia Balcanica 18.1 (2012): 17-24.

15. Moore PD, JA Webb, ME Collinson. "Pollen Analysis, 2nd Edition”. Blackwell, Oxford (1991): 1-216

16. Nilsson S, J Praglowski. "Pollen and Spores: Morphology and Plant Taxonomy". Erdtman.s Handbook of Palynology. Munksgaard (1992): 132-142.

17. Nowicke JW, JJ Skvarla. "Pollen morphology: The potential influence in higher order systematics". Annl. Missouri Bot. Gard. 66(1979): 633-700.

18. Perveen A. "A preliminary study of the pollen flora of Karachi. Ph.D Thesis. University of Karachi, Karachi, 1993.

19. Sarkar AK, M Dey, M Mazumder. "Study of pollen morphology of some common economically important plants of Jalpaiguri district, West Bengal, India". International Journal of Botany Studies 2.4 (2017): 34-37

20. Siddiqui T, M Qaiser. "A palynological study of the family gramineae from Karachi”. Pak J Bot 20 (1988): 161-76.

21. Zavada MS. "Comparative morphology of monocot pollen and evolutionary trends of apertures and wall structure". Bot Rev. 49(1983): 331-79.

\section{Cite this article as:}

Sandip Kumar Maity, Arjun Patra, Bikram Pal and Arati Malakar. Palyno-Taxonomic study of some members of Malvaceae in Purba Medinipur, West Bengal. Annals of Plant Sciences 7.2 (2018) pp. 2069-2072

do $\mathrm{http://dx.doi.org/10.21746/aps.2018.7.2.15}$

Source of support: Department of Botany of Tamralipta Mahavidyalaya

\section{Conflict of interest: Nil}

